\title{
NOTE
}

\section{Differentiation of Mycoplasma and Acholeplasma}

\author{
J. D. POLLACK \\ Department of Medical Microbiology, College of Medicine, The Ohio State University, \\ Columbus, Ohio 43210
}

All Acholeplasma species can incorporate acetate radioactivity into their lipids, and have reduced nicotinamide adenine dinucleotide oxidase activity localized in membrane fractions. No Mycoplasma species tested possesses these properties.

The genera Acholeplasma and Mycoplasma are distinguished by their cholesterol requirement $(1,6-8)$. Other differences have been noted and may be useful in their distinction (3).

We have presented evidence that some Acholeplasma spp. can incorporate acetate radioactivity into their lipids and Mycoplasma spp. cannot $(2,5)$. We have also shown that reduced nicotinamide adenine dinucleotide $(\mathrm{NADH})$ oxidase activity is localized in the membrane of Acholeplasma spp. but is found in the supernatant fractions of Mycoplasma spp. (3). This study extends these findings to all known $\mathrm{Ach}$ oleplasma spp. and supports the general taxonomic usefulness of these assays to differentiate Mycoplasma and Acholeplasma.

Organisms. Acholeplasma oculi (19L) (A. oculusi, per Bergey's Manual of Determinative Bacteriology, 8th ed.), A. equifetale (N93), and A. laidlawii B (PG9) were obtained from J. Tully, National Institutes of Health, Bethesda, Md. Mycoplasma pneumoniae (CL8) was obtained from N. L. Somerson, The Ohio State University. A. laidlawii B (PG9), isolate PS, was obtained from P. Smith, University of South Dakota, Vermillion, and had lost some of its pigmentation without noticeable alteration in serological specificity.

Procedure. For the incorporation of acetate radioactivity into lipids we used SSR2 broth medium for the growth of all organisms (4). Otherwise, procedures for this assay were those described by Herring and Pollack (2).

For the assessment of NADH oxidase activity, the materials and methods previously described were used (3).

The amount of acetate radioactivity incorporated into the lipids and the ratio $(\mathrm{M} / \mathrm{S})$ of membrane (M) to supernatant (S) NADH oxidase activity in the five test organisms are shown in Table 1.

A. oculi, A. equifetale, A. laidlawii $\mathrm{B}$, isolate $\mathrm{PS}$, and the control $A$. laidlawii $\mathrm{B}$ incorporated
TABLE 1. Incorporation of radioactivity from acetate into lipids by growing cells and the ratio of $N A D H$ oxidase activity in membrane and supernatant fractions in Mollicutes ${ }^{a}$

\begin{tabular}{|c|c|c|c|}
\hline \multirow[b]{2}{*}{ Strain } & \multicolumn{2}{|c|}{$\mathrm{dpm} / \mathrm{mg}$ of lipid } & \multirow[b]{2}{*}{$\mathbf{M} / \mathbf{S}^{b}$} \\
\hline & $\begin{array}{l}{\left[1-{ }^{14} \mathrm{C}\right]-} \\
\text { Acetate }\end{array}$ & $\begin{array}{l}{\left[U^{-3} \mathrm{H}\right]-} \\
\text { Acetate }\end{array}$ & \\
\hline $\begin{array}{l}\text { Acholeplasma } \\
\quad \text { laidlawii B } \\
\text { (PG9) }\end{array}$ & 163,129 & 694,368 & $763.22^{c}$ \\
\hline $\begin{array}{l}\text { A. laidlawii B } \\
\text { (PG9, PS) }\end{array}$ & $\mathrm{ND}^{d}$ & 309,343 & 22.05 \\
\hline A. oculi $(19 \mathrm{~L})$ & $147,451^{e}$ & 410,001 & 118.27 \\
\hline $\begin{array}{l}\text { A. equifetale } \\
\text { (N93) }\end{array}$ & 290,117 & $1,135,493$ & 9.46 \\
\hline $\begin{array}{l}\text { Mycoplasma } \\
\text { pneumoniae } \\
\text { (CL8) }\end{array}$ & 80 & 438 & $0.02^{c}$ \\
\hline
\end{tabular}

${ }^{a}$ Means of data from two to four different batches of organisms.

${ }^{b}$ Ratio of membrane (M) to supernatant (S) NADH oxidase activity, expressed as moles of NADH oxidized per minute per milligram of protein.

${ }^{c}$ Pollack (3).

${ }^{d}$ ND, Not done.

${ }^{e}$ Herring and Pollack (2).

acetate radioactivity into their lipids. The NADH oxidase activity of the acholeplasmas was localized in the membrane fractions, resulting in $\mathrm{M} / \mathrm{S}$ ratios higher than 1 . By contrast, the control $M$. pneumoniae did not incorporate any significant amount of acetate radioactivity into the recovered lipid fraction.

The data also suggests that $\left[U-{ }^{3} \mathrm{H}\right]$ acetate is useful as a radioisotope source for labeling the lipids of acholeplasmas in order to differentiate them from mycoplasmas.

All six known species of Acholeplasma can incorporate acetate radioactivity into their lipids and have NADH oxidase activity localized in their membrane fractions, as now shown by this work and other data $(2,3)$. The localization of $\mathrm{NADH}$ oxidase activity in the membrane of 
Acholeplasma species has been directly shown by light and electron microscopy (9). On the other hand, all nine Mycoplasma species that have been tested do not incorporate acetate radioactivity into their lipids and have NADH oxidase activity localized in supernatant fractions $(2,3)$. These two physiological distinctions between the Mycoplasma and Acholeplasma are clear and are presently without exception. These tests appear to be taxonomically useful and generally reflect significant differences in the membrane architecture and metabolism of these genera.

These and earlier studies indicate that $A$. $a x$ anthum (S743), A. modicum (PG49), A. laidlawii A (PG8), A. equifetale (N93) and A. laidlawii B (PG9, PS) produce less visibly colored cells in SSR2 medium than other isolates. Batches of Acholeplasma cells with less pigment have lower $\mathrm{M} / \mathrm{S}$ ratios than those strains producing apparently more.

The excellent assistance of Joan C. Davis was most appreciated.

\section{REPRINT REQUESTS}

Address reprint requests to: Dr. J. D. Pollack, Department of Medical Microbiology, Graves Hall \#5072, 333 W. Tenth
Ave., College of Medicine, The Ohio State University, Columbus, $\mathrm{OH} 43210$.

\section{LITERATURE CITED}

1. Edward, D. G. ff., and E. A. Freundt. 1970. Amended nomenclature for strains related to Mycoplasma laidlawii. J. Gen. Microbiol. 62:1-2.

2. Herring, P. K., and J. D. Pollack. 1974. Utilization of $\left[1-{ }^{14} \mathrm{C}\right]$ acetate in the synthesis of lipids by acholeplasmas. Int. J. Syst. Bacteriol. 24:73-78.

3. Pollack, J. D. 1975. Localization of reduced adenine dinucleotide oxidase activity in Acholeplasma and $M y$. coplasma species. Int. J. Syst. Bacteriol. 25:108-113.

4. Pollack, J. D., N. L. Somerson, and L. B. Senterfit. 1970. Isolation, characterization, and immunogenicity of Mycoplasma pneumoniae membranes. Infect. Immun. 2:326-339.

5. Pollack, J. D., and M. E. Tourtellotte. 1967. Synthesis of saturated long chain fatty acids from sodium acetate1- $\mathrm{C}^{14}$ by Mycoplasma. J. Bacteriol. 93:636-641.

6. Razin, S., and J. G. Tully. 1970. Cholesterol requirement of mycoplasmas. J. Bacteriol. 102:306-310.

7. Smith, P. F., T. A. Langworthy, and W. R. Mayberry. 1973. Lipids of mycoplasmas. Ann. N. Y. Acad. Sci. 225:22-27.

8. Tully, J. G. 1973. Biological and serological characteristics of the acholeplasmas. Ann. N. Y. Acad. Sci. 225:74-93.

9. Vinther, O., and E. A. Freundt. 1977. Ultrastructural localization of tellurite reduction in Acholeplasma species. Acta Pathol. Microbiol. Scand. Sect. B. 85: $184-188$. 